\title{
EFFECT OF SAWDUST ON COHESION OF SAND-SAWDUST MIXTURE
}

\author{
Mahdi Keramatikerman \\ Engineer, Arup Australia, 61-73 Sturt Street, \\ Suncorp Tower, Townsville QLD 4810, Australia \\ Amin Chegenizadeh \\ Senior Lecturer, Department of Civil Engineering, \\ Curtin University of Technology, Kent Street, Bentley, Perth, Western Australia 6102, Australia \\ Hamid Nikraz \\ Professor, Department of Civil Engineering, \\ Curtin University of Technology, Kent Street, Bentley, Perth, Western Australia 6102, Australia.
}

\begin{abstract}
Shear stress is one of important factor in any geotechnical design. Application of sawdust into soil recently being emphasized by researcher in this area. This study, considers the effect of sawdust addition into cohesion value of sand.
\end{abstract}

Keywords - Cohesion, Sawdust, Shear

\section{INTRODUCTION}

Shear stress at failure and its relevant parameters are surely those of importance in design of geotechnical infrastructure. Based on mohr-coulomb theory the shear stress at failure depends on cohesion and friction angle. Sand alone being investigated by researcher's example [1,2]. The idea of stabilization technique then comes to effect to see different potential of waste and by-product applications. The by-product such as fly ash [3-7]. Some other research has been done on application fibre into soil [8-12]. Tire application into soil also was studied by [13-17]. Lime as one of the common stabilization technique also being applied in soils [18-21]. There have been other aspects as outlined in [22-32] which all proved that importance application of sawdust into soil. Therefore, this study investigates the effect of sawdust on the cohesion and friction angle of soils.

\section{MATERIALS}

The employed materials can be listed as:

$$
\text { a) Sand: }
$$

The sand which was used in this study referred as yellow sand. The SG was 2.65. The medina size of particle was $1.2 \mathrm{~mm}$.

\section{b) Sawdust} $36 \mu \mathrm{m}$.

\author{
C) cement \\ Portland cement was used in this study.
}

\section{COMPACTION TESTING}

In the first stage, the compaction values were derived. The results of compaction can be seen in the table 1:

Table 1 OMC and MDD values of mixes

\begin{tabular}{|c|c|c|c|c|}
\hline Sample Id & Sawdust & PC\% & OMC \% & MDD \\
\hline S-PC-SW3 & 3 & 5 & 17 & 1.49 \\
\hline S-PC-SW5 & 5 & 5 & 18.2 & 1.45 \\
\hline S-PC-SW7 & 7 & 5 & 18.7 & 1.34 \\
\hline $\begin{array}{c}\text { S-PC- } \\
\text { SW10 }\end{array}$ & 10 & 5 & 21 & 1.31 \\
\hline
\end{tabular}

Figure1 shows that MDD values of samples were decreased by addition of SW percentage.

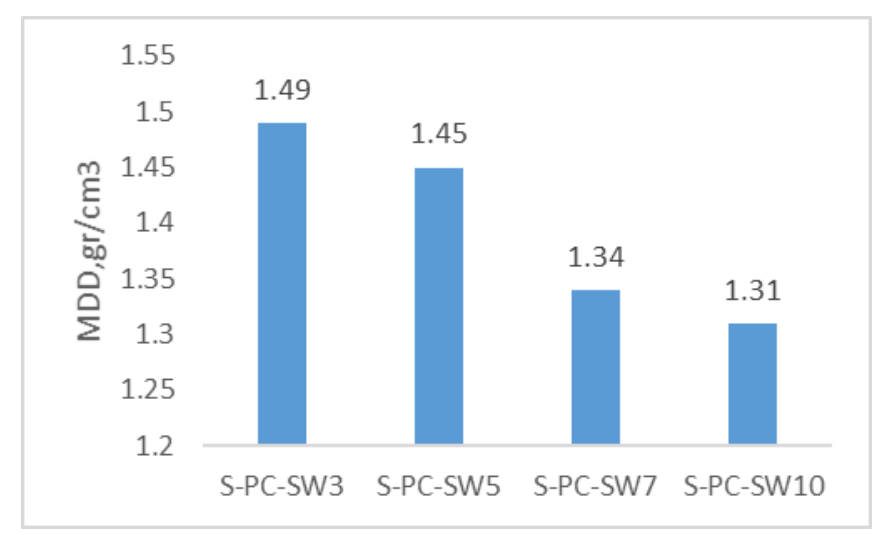

Figure 1 MDD values for each mixture 


\section{International Journal of Engineering Applied Sciences and Technology, 2020 \\ Vol. 4, Issue 11, ISSN No. 2455-2143, Pages 14-16 \\ Published Online March 2020 in IJEAST (http://www.ijeast.com)}

Figure 2 shows that increasing in SW percentage increases the OMC values.

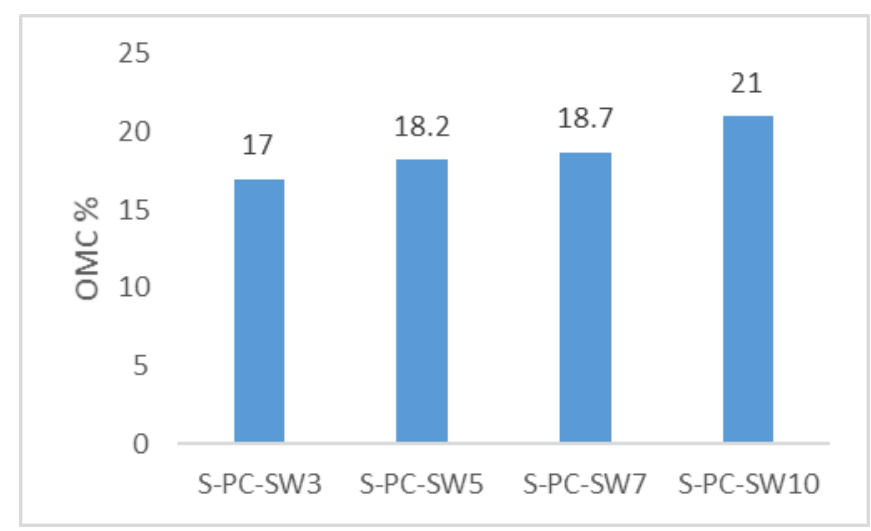

Figure 2 OMC values of mixes

\section{SHEAR TEST}

Direct shear test run with $0.1 \mathrm{~mm} / \mathrm{min}$. The sample were prepared in accordance with OMC and MDD of mixes. Cohesion of mixes were recorded and presented in figure 3 . As can be seen, with increasing in sawdust percentage the cohesion of mixes was increased.

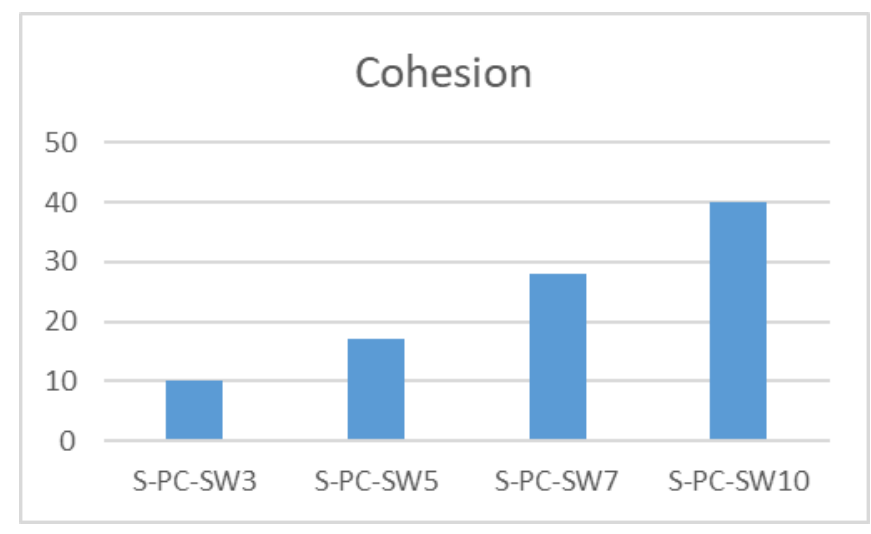

Figure 3 Cohesion of mixes varying SW

The friction angle is recorded and can be seen in figure 4.

The friction angle is decreased with increasing in sawdust percentage.

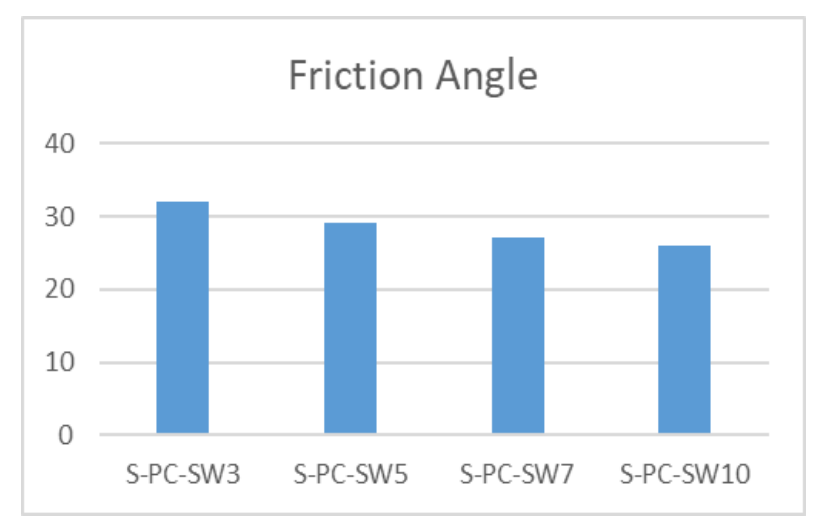

Figure 4 Friction angle of mixes varying SW

\section{CONCLUSION}

A series of shear tests conducted to investigate effect of sawdust on cohesion behavior of the sawdust sand mixtures. The results showed that increasing the sawdust increased the cohesion and reduced the friction angle.

\section{REFERENCES}

[1] Aldaood, A., (2019) Impact of fine materials on the saturated and unsaturated behavior of silty sand soil. Ain Shams Engineering Journal.

[2] Al-Rkaby AHJ, Chegenizadeh A, Nikraz H. (2016). Directional-dependence in the mechanical characteristics of sand: a Review International Journal of Geotechnical Engineering 10 (5), 499-509

[3] Keramatikerman, M., Chegenizadeh, A., \& Nikraz, H. (2018). Effect of Flyash on Post-Cyclic Behavior of Sand. Journal of Earthquake Engineering, 1-13.

[4] Keramatikerman, M., Chegenizadeh, A., Nikraz, H., \& Sabbar, A. S. (2018a). Effect of flyash on liquefaction behaviour of sand-bentonite mixture. Soils and foundations, 58(5), 1288-1296.

[5] Dahale, P.P., P.B. Nagarnaik, and A.Y. Gajbhiye, (2017) Engineering Behavior of Remolded Expansive Soil with Lime and Flyash. Materials Today: Proceedings. 4(9): p. 10581-10585.

[6] Al-Malack, M.H., et al., (2016) Stabilization of indigenous Saudi Arabian soils using fuel oil flyash. Journal of King Saud University - Engineering Sciences,. 28(2): p. 165-173.

[7] Keramatikerman M, Chegenizadeh A, Nikraz H. (2017a). Experimental study on effect of flyash on liquefaction resistance of sand Soil Dynamics and Earthquake Engineering 93, 1-6

[8] Chegenizadeh, A., Nikraz, H. (2011a). "Investigation on strength of fiber reinforced clay" Advanced Materials Research 261-263, pp. 957-963. 
[9] Chegenizadeh, A. and H. Nikraz, (2011b). "Study on modulus of elasticity of reinforced clay" - Advanced Materials Research. 243-249: pp. 5885-5889, 2011.

[10] Chegenizadeh, A. and H. Nikraz, (2011c). Composite Soil: Fiber Inclusion and Strength, Journal of Advanced Materials Research 1646

[11] Chegenizadeh, A. and H. Nikraz, (2012). Composite Clayey Sand and Short Fiber, Advanced Materials Research 383, 2764-2769

[12] Chegenizadeh, A., Keramatikerman, M., \& Nikraz, H. (2018b). Liquefaction resistance of fibre reinforced lowplasticity silt. Soil Dynamics and Earthquake Engineering, 104, 372-377.

[13] Chegenizadeh A, Keramatikerman M, Panizza S, Nikraz H. (2017). Effect of powdered recycled tire on sulfate resistance of cemented clay. Journal of Materials in Civil Engineering. 2017 Oct 1;29(10):04017160.

[14] Jafari, M. and M. Esna-ashari (2012), Effect of waste tire cord reinforcement on unconfined compressive strength of lime stabilized clayey soil under freeze-thaw condition. Cold Regions Science and Technology,. 82: p. 21-29.

[15] Chegenizadeh, A., Keramatikerman, M., Dalla Santa, G., \& Nikraz, H. (2018a). Influence of recycled tyre amendment on the mechanical behaviour of soilbentonite cut-off walls. Journal of cleaner production, 177, 507-515

[16] Mohajerani, A., et al., (2020) Recycling waste rubber tyres in construction materials and associated environmental considerations: A review. Resources, Conservation and Recycling155: p. 104679.

[17] Chegenizadeh, A., Keramatikerman, M., Panizza, S., \& Nikraz, H. (2017). Effect of powdered recycled tire on sulfate resistance of cemented clay. Journal of Materials in Civil Engineering, 29(10), 04017160

[18] Gidday, B.G. and S. Mittal,(2020) Improving the characteristics of dispersive subgrade soils using lime. Heliyon, 6(2): p. e03384.

[19] Amiralian S, Chegenizadeh A, Nikraz H (2012a) Laboratory investigation on the compaction properties of lime and fly ash composite, Proceedings of the International Conference on Civil and Architectural applications (ICCAA'2012) 79-83

[20] James, J., Sugarcane press mud modification of expansive soil stabilized at optimum lime content: Strength, mineralogy and microstructural investigation. Journal of Rock Mechanics and Geotechnical Engineering, 2020.

[21] Amiralian S, Chegenizadeh A, Nikraz H (2012b) Laboratory investigation on the effect of lime on compressibility of soil, Proceedings of the International Conference on Civil and Architectural applications (ICCAA'2012) 89-93

[22] Keramatikerman, M., Chegenizadeh, A., Yilmaz, Y., \& Nikraz, H. (2018b). Effect of Lime Treatment on Static
Liquefaction Behavior of Sand-Bentonite Mixtures. Journal of Materials in Civil Engineering, 30(11), 06018017.

[23] Chegenizadeh, A., \& Keramatikerman, M. (2017). Mitigating sulphate attacks in geotechnical engineering Hauppauge, New York, USA Nova Science Publishers. (pp. 1-165).

[24] Chegenizadeh, A., Keramatikerman, M., Miceli, S., Nikraz, H., Salih Sabbar, A. (2020). Investigation on Recycled Sawdust in Controlling Sulphate Attack in Cemented Clay. Appl. Sci., 10, 1441.

[25] Keramatikerman, M., Chegenizadeh, A., \& Nikraz, H. (2017c). An investigation into effect of sawdust treatment on permeability and compressibility of soilbentonite slurry cut-off wall. Journal of Cleaner Production, 162, 1-6.

[26] Keramatikerman M, Chegenizadeh A, Terzaghi S. (2019) Review on Effect of Sugarcane Bagasse Ash as an Additive in Construction Industry. 2019. EJGE. Vol.24 Bun. 02.

[27] Chegenizadeh, A., Keramatikerman, M., \& Nikraz, H. (2016). Flexible pavement modelling using Kenlayer. EJGE, 21, 2467-2479.

[28] Keramatikerman, M., Chegenizadeh, A., \& Pu, H. (2017a). Effect of atrazine contamination on compressibility and permeability characteristics of clay. Geotechnical Testing Journal, 40(6), 936-950.

[29] Al-Rkaby AHJ, Chegenizadeh A, Nikraz H. (2017). Anisotropic strength of large scale geogrid-reinforced sand:experimental study Soils and foundations 57 (4), $557-574$

[30] Keramatikerman M, Chegenizadeh A, Nikraz H. Effect of sawdust on Cohesion of Sand-Sawdust mixture. International Journal of Engineering Applied Sciences and Technology (IJEAST), 2020 (accepted).

[31] Keramatikerman M, Chegenizadeh A, Nikraz H. SOIL STABILISATION USING GLASS POWDER. International Journal of Engineering Applied Sciences and Technology (IJEAST), 2020 (accepted)

[32] Keramatikerman M, Chegenizadeh A, Nikraz $H$. STRENGTH OF CEMENTED FLY ASH SOIL. International Journal of Engineering Applied Sciences and Technology (IJEAST), 2020 (accepted). 